Article

\title{
Quantifying the Impacts of Climate Change, Coal Mining and Soil and Water Conservation on Streamflow in a Coal Mining Concentrated Watershed on the Loess Plateau, China
}

\author{
Qiaoling Guo ${ }^{1,2,3}$, Yaoyao Han ${ }^{1}$, Yunsong Yang ${ }^{4, *}$, Guobin Fu ${ }^{5}$ and Jianlin $\mathrm{Li}^{1,3}$ \\ 1 Institute of Resource and Environment, Henan Polytechnic University, Jiaozuo 454003, China; \\ guoqiaoling@hpu.edu.cn (Q.G.); 15139179673@163.com (Y.H.); lijianlin@hpu.edu.cn (J.L.) \\ 2 School of Water Resources \& Environmental Engineering, East China University of Technology, \\ Nanchang 330000, China \\ 3 Collaborative Innovation Center of Coalbed Methane and Shale Gas for Central Plains Economic Region, \\ Jiaozuo 454003, China \\ 4 Institute of Business Management, Henan Polytechnic University, Jiaozuo 454003, China \\ 5 CSIRO Land and Water, Private Bag 5, Wembley, WA 6913, Australia; GUOBIN.FU@CSIRO.AU \\ * Correspondence: yangyunsong@hpu.edu.cn or yys7401@163.com; Tel.: +1-553-899-2635
}

Received: 21 March 2019; Accepted: 28 April 2019; Published: 21 May 2019

\begin{abstract}
The streamflow has declined significantly in the coal mining concentrated watershed of the Loess Plateau, China, since the 1970s. Quantifying the impact of climate change, coal mining and soil and water conservation (SWC), which are mainly human activities, on streamflow is essential not only for understanding the mechanism of hydrological response, but also for water resource management in the catchment. In this study, the trend of annual streamflow series by Mann-Kendall test has been analyzed, and years showing abrupt changes have been detected using the cumulative anomaly curves and Pettitt test. The contribution of climate change, coal mining and SWC on streamflow has been separated with the monthly water-balance model (MWBM) and field investigation. The results showed: (1) The streamflow had an statistically significant downward trend during 1955-2013; (2) The two break points were in 1979 and 1996; (3) Relative to the baseline period, i.e., 1955-1978, the mean annual streamflow reduction in 1979-1996 was mainly affected by climate change, which was responsible for a decreased annual streamflow of $12.70 \mathrm{~mm}$, for $70.95 \%$, while coal mining and SWC resulted in a runoff reduction of $2.15 \mathrm{~mm}, 12.01 \%$ and $3.05 \mathrm{~mm}, 17.04 \%$, respectively; (4) In a recent period, i.e., 1997-2013, the impact of coal mining on streamflow reduction was dominant, reaching $29.88 \mathrm{~mm}, 54.24 \%$. At the same time, the declining mean annual streamflow induced through climate change and SWC were $13.01 \mathrm{~mm}, 23.62 \%$ and $12.20 \mathrm{~mm}, 22.14 \%$, respectively.
\end{abstract}

Keywords: streamflow reduction; climate change; coal mining; SWCM; coal mining concentrated watershed; the Loess Plateau

\section{Introduction}

Over the second half of the 20th century, the two factors which affected the change of catchment hydrology were climate change and human activities [1]. Plenty of studies have indicated that the streamflow of many rivers has changed due to climate change and anthropogenic activities [2,3], especially in arid and semi-arid regions. Climate change, for example, the redistribution of precipitation and temperature change, has affected hydrological systems and water resources [4,5]. Human activities, such as agricultural irrigation, cultivation, dam construction, reservoir operation, soil and water 
conservation (SWC), urbanization construction and coal mining could also affect hydrological processes, resulting in natural ecosystem and water resource problems [6,7].

The Loess Plateau, located in the middle reaches of the Yellow River, is the most severe soil and water loss region worldwide [8]. Most areas of the Loess Plateau comprises gully-hill dominated regions, with the most widely distributed loess on Earth. Intensive soil and water loss has resulted in water shortages, land productivity decline, and river ecosystem and environmental degradation. Soil from tributaries in middle reaches of the Yellow River is the major source of sediment in the lower reach of the Yellow River [9]. SWC are important measures for improving the ecosystem and the environment of the Loess Plateau. Since the 1970s, large-scale SWCs have been carried out by the Chinese government [10], which has brought about major changes to the runoff conditions and hydrological characteristics in tributaries of middle reaches of the Yellow River, and has had an impact on storm floods and river runoff [11,12]. The maximum runoff utilization rate of the SWC is $63 \%$, which can significantly reduce the amount of water entering the river [13]. The Loess Plateau is rich in mineral resources [14], which plays a critical role on energy sources in China's economic development. The Shenfu-Dongsheng coalfield, accounting for $1 / 4$ of the China's coal reserves, is located in the northern edge of Loess Plateau [15]. Subsidence and cracks formed by coal mining have changed the surface conditions, and thus, have altered runoff generation and confluence, leading to degradation of river ecological environment in the mining area [16,17].

The Kuye River Basin is located in a wind and water erosion interlaced area in the northern of the Loess Plateau [18]. It is a typical loess hilly landform [19], and is one of the most severely water and soil losing areas on the Loess Plateau. The Shenfu-Dongsheng coalfield is through the middle of the Kuye River Basin, which is the main source of sediment in the lower Yellow River. Su et al. analyzed precipitation and runoff changing trend in Kuye River Basin [20]. Guo et al. studied the trend of inner-annual runoff in Kuye River Basin [21]. Zhao et al. analyzed the flood characteristics and their changing trends in the Kuye River Basin [22]. Liu et al. and Bai et al. studied the impact of climate change and anthropogenic activities on runoff variation, indicating that SWC and coal mining had had an important impact on the runoff change in Kuye River Basin [23,24].

Three groups methods are used for assessing the effects of climate change and human activities on runoff variation: the paired catchments approach, the statistical method and hydrological modeling [25]. The paired catchments approach is usually considered in small experimental catchments; the statistical method can only analyze the impact of climate change and human activities on runoff variation, as it lacks a physical mechanism. Hydrological modeling is widely used to assess the effects of climate change and human activity on runoff variation. Wang et al. used a monthly water balance model to simulate the runoff of nine tributaries in the middle reaches of the Yellow River, achieving high simulation accuracy [26]. Xing et al. and Guo et al. simulated the runoff in Kuye River Basin by monthly water balance model and received satisfactory results $[27,28]$. Cheng et al. simulated daily and monthly discharges by SWAT model, and found that it is not effective [29]. Li et al. simulated the monthly runoff in Kuye River Basin using SWAT model, and the simulation effect was not satisfactory [30]. Considering that the monthly water balance model has a simple structure, few parameters and a good simulation effect, this method is used to separate the effects of climate change and human activities in this study.

In this work the objectives are: (1) Analysis of the annual streamflow variation since 1950s; and (2) Quantitative assessments of climate change, coal mining and SWC impacts on runoff decline in past 60 years. This work will provide a better understanding of the interactions between humans and nature, while also provide important insights into water-resource management in the Kuye River Basin. 


\section{Studied Watershed and Data}

\subsection{Studied Watershed}

The Kuye River Basin is a first-tributary in the middle Yellow River. It has a main stream length of $242 \mathrm{~km}$ and a drainage area of $8706 \mathrm{~km}^{2}$ [28]. There are two major tributaries (Wulanmulun River and Beiniuchuan River) in the upper reaches, and a large number of coal mine are along the two tributaries. The water system of the Kuye River Basin is shown in Figure 1. Affected by continental monsoons, the climate fluctuates dramatically throughout the year. The precipitation from June to September accounts for $75-81 \%$ of the annual total [31]. Rain storms usually take place in summer, especially in July and August. The drainage landform mainly consists of wind-dust region and hill-gully loess region [32]. The wind-dust region is relatively flat with hardly any vegetation, and the hill-gully loess region is covered by exposed soft bedrock.

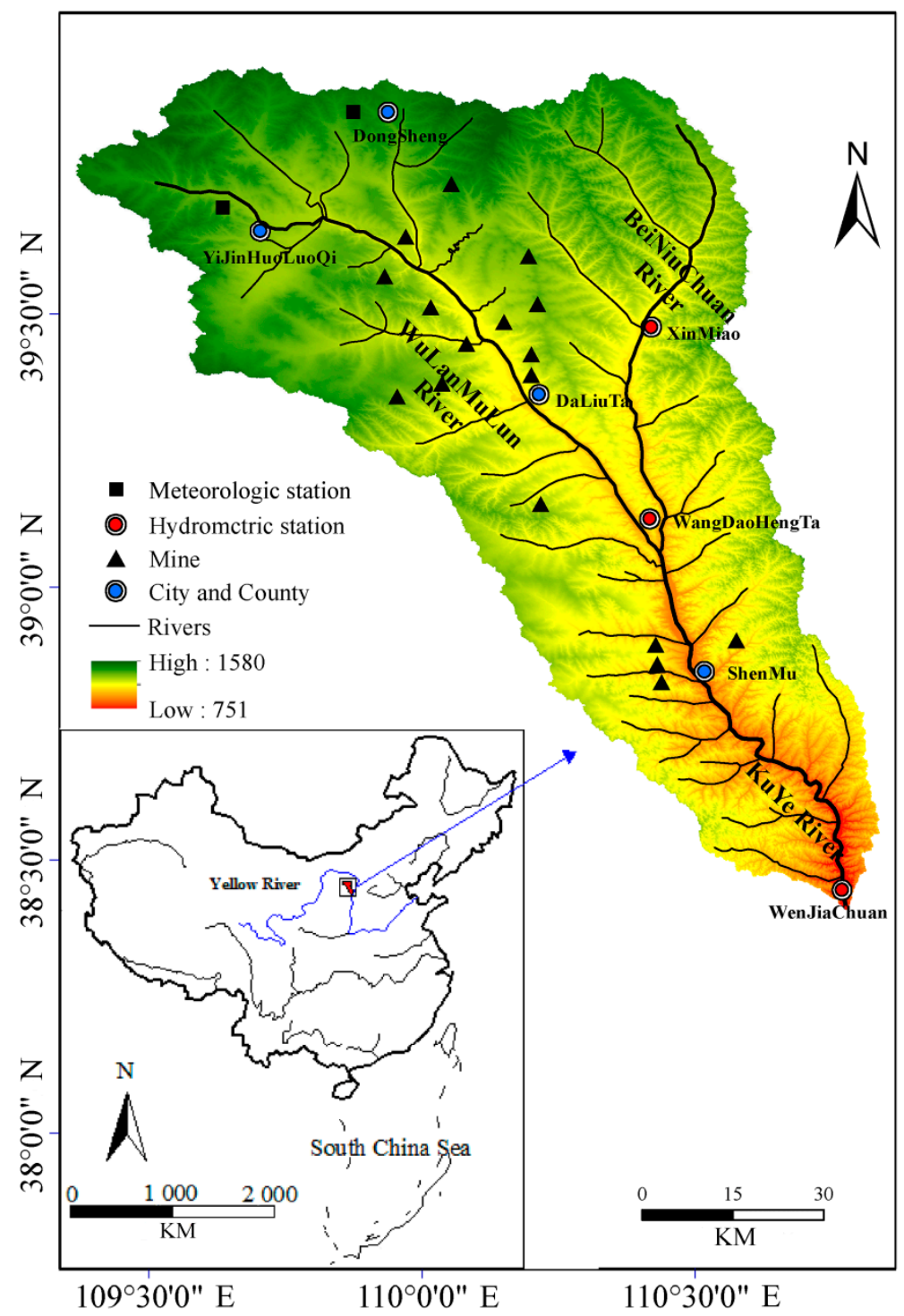

Figure 1. The sketch map of the Kuye River Watershed.

The coal resources are rich in the Kuye River Basin. There are 209 coal mines on both sides of the river; the coal seams are shallow, and the exploited mine areas reach $2482 \mathrm{~km}^{2}$, which accounts for $28.51 \%$ of the basin areas. According to the survey data, the raw coal output was $6.25 \times 10^{6} \mathrm{t}$ in 1991 , $31.293 \times 10^{6} \mathrm{t}$ in 2002 , and $172.262 \times 10^{6} \mathrm{t}$ in 2011, with the average annual growth of $7.905 \times 10^{6} \mathrm{t}$. 
Along with the coal mining amount increasing, coal mining subsidence areas were $26.01 \mathrm{~km}^{2}$ in 1991 , $48.82 \mathrm{~km}^{2}$ in 2000 , and $266.15 \mathrm{~km}^{2}$ in 2011 , and the average annual growth reached to $11.435 \mathrm{~km}^{2}$. The large surface cracks in the subsidence changed the surface characteristics, and impacted the streamflow (Figure 2).

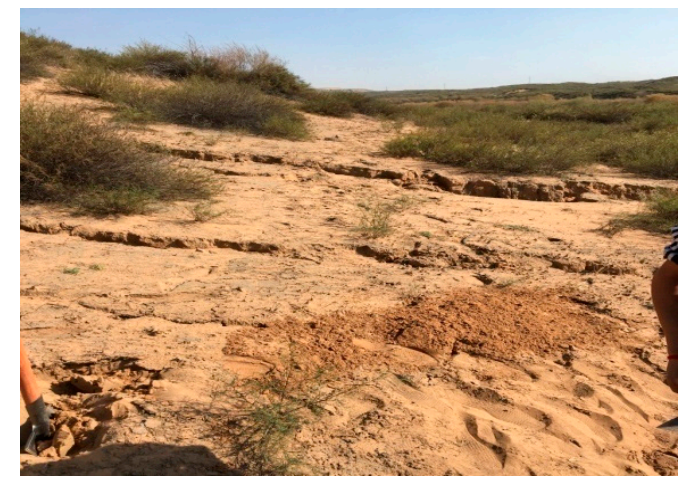

Figure 2. The cracks in the coal mining subsidence.

Water and soil loss are serious in the Kuye River Basin. The SWC consists of terraces, grassland, afforestation, and the construction of sediment-trapping dams. Before 1979, the areas of SWC were $609.42 \mathrm{~km}^{2}$. From 1980s to 1990s, the areas of SWC reached $1480.02 \mathrm{~km}^{2}$ in the late 1990s [33]. By 2009, the areas of SWC were $3739.90 \mathrm{~km}^{2}$, and the sediment-trapping dams were 1548 . The increasing of SWC also transformed the surface characteristics, and impacted on runoff.

In Kuye River Basin, human influence on streamflow includes coal mining, SWC and the water abstraction from the river for domestic, irrigation, and industry uses. Among these influencing factors, coal mining and SWC are mainly impact factors, and the water abstraction from the river is only a small part $[34,35]$. Therefore, this study separated the impact of coal mining and SWC on runoff.

\subsection{Data}

The daily streamflow records of Wenjiachuan hydrological station which is the furthest downstream hydrological station ( $8645 \mathrm{~km}^{2}$ at Wenjiachuan hydrological station) were used in this study. The daily streamflow data was provided by the Yellow River Conservancy Commission. The data of daily precipitation, average daily temperature was from two meteorological stations (Yijinhuoluo and Dongsheng), and four hydrological stations. The data of meteorological stations was obtained from the China Meteorological Administration, and the data of hydrological stations (Wangdaohengta, Xinmiao, Shenmu, and Wenjiachuan) was from the Yellow River Conservancy Commission. All the data were from 1955 to 2013. The monthly (year) streamflow, the monthly (year) precipitation, and the average monthly (year) temperature were calculated from daily discharge, daily rainfall, and average daily temperature.

\subsection{Methods}

First, the modified Mann-Kendall trend test was used to analyze the trends of annual streamflow [36]. Then, cumulative anomaly curves and the Pettitt test were applied to detect the abrupt change years of streamflow variables [37]. Finally, the contributions of climate change, coal mining and SWC on streamflow decreasing in the same period was analyzed using the monthly water-balance model (MWBM) and survey data. The brief introduction of MWBM, and the methods of distinguishing the impacts of climate change, coal mining and SWC on streamflow reduction are presented below. 


\subsubsection{Separating Climate Change, Coal Mining and SWC Impacts on the Streamflow}

In an attempt to separate the effect of climate change, coal mining and SWC, we need to choose a baseline period. The streamflow difference between the baseline period and human induce period is the impact of climate change, coal mining and SWC, and is calculated as follows:

$$
\Delta \mathrm{Q}_{\mathrm{cm}}+\Delta \mathrm{Q}_{\mathrm{sb}}+\Delta \mathrm{Q}_{\mathrm{c}}=\mathrm{Q}_{\mathrm{i}}-\mathrm{Q}_{\mathrm{b}}
$$

where $\Delta \mathrm{Q}_{\mathrm{c}}, \Delta \mathrm{Q}_{\mathrm{cm}}$ and $\Delta \mathrm{Q}_{\mathrm{sb}}$ are the contributions of climate change, coal mining and SWC on streamflow change, respectively; $Q_{i}, Q_{b}$ are the observed streamflow during the human induced period and baseline periods, respectively.

$$
\begin{gathered}
\Delta \mathrm{Q}_{\mathrm{cm}}+\Delta \mathrm{Q}_{\mathrm{sb}}=\mathrm{Q}_{\mathrm{i}}-\mathrm{Q}_{\mathrm{m}} \\
\Delta \mathrm{Q}_{\mathrm{c}}=\mathrm{Q}_{\mathrm{m}}-\mathrm{Q}_{\mathrm{b}} \\
\Delta \mathrm{Q}_{\mathrm{sb}}=\sum_{\mathrm{i}=1}^{4} \varepsilon_{\mathrm{i}} \mathrm{A}_{\mathrm{i}}
\end{gathered}
$$

where $Q_{m}$ is the reconstructed streamflow by the monthly water-balance model (MWBM), $\varepsilon_{i}$ is the water reduction coefficient, which use the research results of the reference [38], $A_{i}$ is areas of terrace, afforestation, grassland and sediment-trapping dams.

The impact percentages from climate change $\left(\eta_{\mathrm{c}}\right)$, coal mining $\left(\eta_{\mathrm{cm}}\right)$ and $\operatorname{SWC}\left(\eta_{\mathrm{sb}}\right)$, are stated as

$$
\begin{gathered}
\eta_{\mathrm{c}}=\frac{\Delta \mathrm{Q}_{\mathrm{c}}}{\Delta \mathrm{Q}_{\mathrm{cm}}+\Delta \mathrm{Q}_{\mathrm{sb}}+\Delta \mathrm{Q}_{\mathrm{c}}} \times 100 \% \\
\eta_{\mathrm{cm}}=\frac{\Delta \mathrm{Q}_{\mathrm{cm}}}{\Delta \mathrm{Q}_{\mathrm{cm}}+\Delta \mathrm{Q}_{\mathrm{sb}}+\Delta \mathrm{Q}_{\mathrm{c}}} \times 100 \% \\
\eta_{\mathrm{sb}}=\frac{\Delta \mathrm{Q}_{\mathrm{sb}}}{\Delta \mathrm{Q}_{\mathrm{cm}}+\Delta \mathrm{Q}_{\mathrm{sb}}+\Delta \mathrm{Q}_{\mathrm{c}}} \times 100 \%
\end{gathered}
$$

The above equations were used to quantify the impacts of climate change, coal mining and SWC on streamflow variance in Kuye River Basin from 1955 to 2013. The next step is to reconstruct natural streamflow using the MWBM.

\subsubsection{Brief Introduction of the MWBM}

The MWBM was developed by the U.S. Geological Survey. It used a monthly accounting procedure based on the methodology, originally proposed by Thornthwaite [39]. Mean monthly temperature and monthly total precipitation are the input files to the model. The input parameters include runoff factor, soil-moisture-storage capacity, rain temperature threshold, maximum melt rate, direct runoff factor, snow temperature threshold and latitude of location. The individual components of the water balance included the amount of monthly precipitation $(\mathrm{P})$ that is rain $\left(\mathrm{P}_{\text {rain }}\right)$ or snow $\left(\mathrm{P}_{\text {rain }}\right)$, direct runoff DRO, snow melt (SM), potential evapotranspiration (PET), soil-moisture storage withdrawal (STW), and runoff [40].

$$
\begin{gathered}
\mathrm{P}_{\text {snow }}=\mathrm{P} \times\left[\frac{\mathrm{T}_{\text {rain }}-\mathrm{T}}{\mathrm{T}_{\text {rain }}-\mathrm{T}_{\text {snow }}}\right] \\
\mathrm{P}_{\text {rain }}=\mathrm{P}-\mathrm{P}_{\text {snow }} \\
\mathrm{DRO}=\mathrm{P}_{\text {rain }} \times \text { drofrac } \\
\mathrm{P}_{\text {remain }}=\mathrm{P}_{\text {rain }}-\mathrm{DRO} \\
\mathrm{SMF}=\frac{\mathrm{T}-\mathrm{T}_{\text {snow }}}{\mathrm{T}_{\text {rain }}-\mathrm{T}_{\text {snow }}} \times \text { meltmax }
\end{gathered}
$$




$$
\begin{gathered}
\mathrm{SM}=\text { snostor } \times \mathrm{SMF} \\
\mathrm{PET}=13.97 \times \mathrm{d} \times \mathrm{D}^{2} \times \frac{4.95 \times \mathrm{e}^{0.062 \times \mathrm{T}}}{100} \\
\mathrm{STW}=\mathrm{ST}_{\mathrm{i}-1}-\left[\mathrm{abs}\left(\mathrm{P}_{\text {total }}-\mathrm{PET}\right) \times\left(\frac{\mathrm{ST}_{\mathrm{i}-1}}{\mathrm{STC}}\right)\right]
\end{gathered}
$$

where $\mathrm{P}_{\text {remain, }} \mathrm{SMF}, \mathrm{ST}, \mathrm{SMF}$ are remaining precipitation, snow melt fraction, soil-moisture storage, and the soil-moisture storage capacity, respectively.

The Nash Sutcliffe coefficient (NSE) and relative error (RE) were used to evaluate the performance of the model. NSE close to 1 and RE close to 0 are the good simulation result. The qualified conditions of simulation are that NSE is much more 0.6 and RE is less than 0.1 [41].

\section{Results}

\subsection{Long-Term Variation of the Annual Streamflow Series}

\subsubsection{Trend Analysis of the Annual Streamflow Series}

The annual streamflow in 1955-2013 at Wenjiachuan hydrological station was shown in Figure 3. The maximum annual streamflow was $13.706 \times 10^{8} \mathrm{~m}^{3}$ and occurred in 1959 . While, the minimum annual streamflow reached $1.187 \times 10^{8} \mathrm{~m}^{3}$ in 2011. The mean annual streamflow from 1955 to 2013 was $5.187 \times 10^{8} \mathrm{~m}^{3}$. Average annual streamflow in 1950s, 1960s, 1970s, 1980s, 1990s and the early 21st century were $6.827 \times 10^{8} \mathrm{~m}^{3}, 7.642 \times 10^{8} \mathrm{~m}^{3}, 6.867 \times 10^{8} \mathrm{~m}^{3}, 5.278 \times 10^{8} \mathrm{~m}^{3}, 4.226 \times 10^{8} \mathrm{~m}^{3}$, and $1.919 \times 10^{8} \mathrm{~m}^{3}$, respectively. Since the 1980s, average annual runoff began to decrease. At the beginning of the 21st century, average annual runoff decreased the most, which only accounted for $37 \%$ of mean annual streamflow. The annual streamflow has an obvious declining gradient of $-0.113 \times 10^{8} \mathrm{~m}^{3} / \mathrm{year}$. When being analyzed using the modified M-K trend test, the annual streamflow during 1955-2013 presented a significant decreasing trend; the $Z_{c}$ reached the value of -2.325 , and passed the 0.05 significance test.

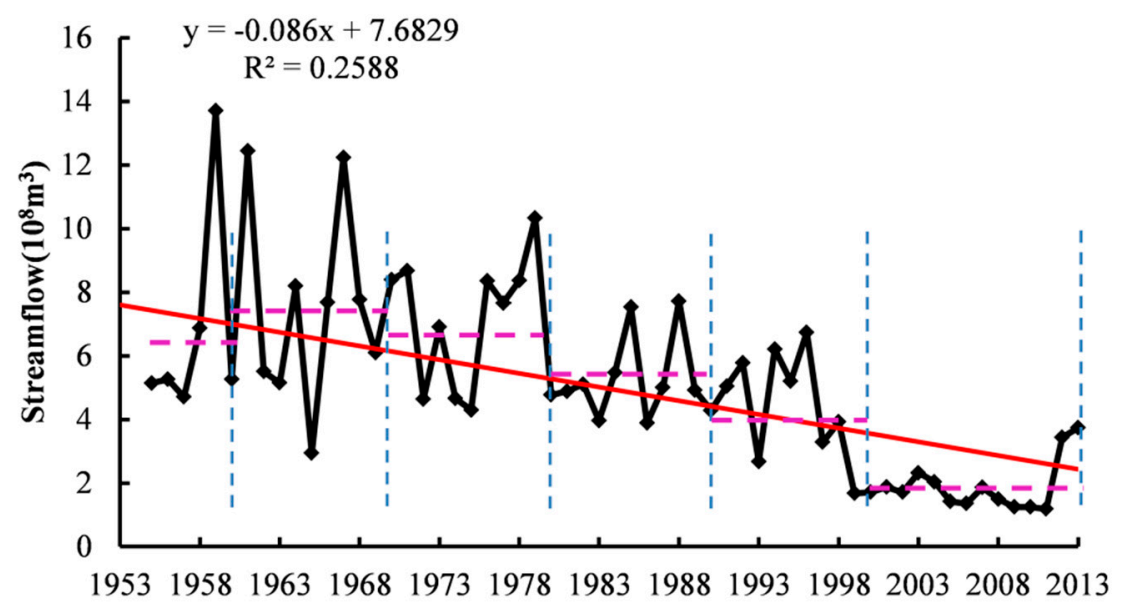

Figure 3. The variation trend of streamflow at Wenjiachuan hydrological station.

\subsubsection{Abrupt Change Years of Annual Streamflow Series}

To detect abrupt changes of annual streamflow change, cumulative anomaly curves and Pettitt test were used. Both Figures 4 and 5 show that the annual streamflow has an increasing trend before 1979, and that it then fluctuated slightly from 1979 to 1996, and finally, declined considerably after 1996. There were two significant change points in 1979 and 1996. According to the two change points, the annual streamflow series were divided into 3 stages which were 1955-1978, 1979-1996, and 1997-2013, respectively. 


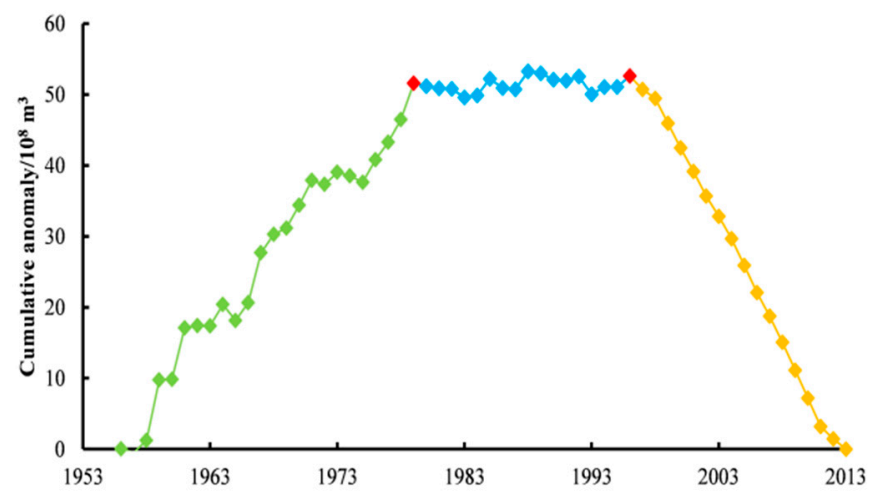

Figure 4. Cumulative anomaly curve of annual streamflow.

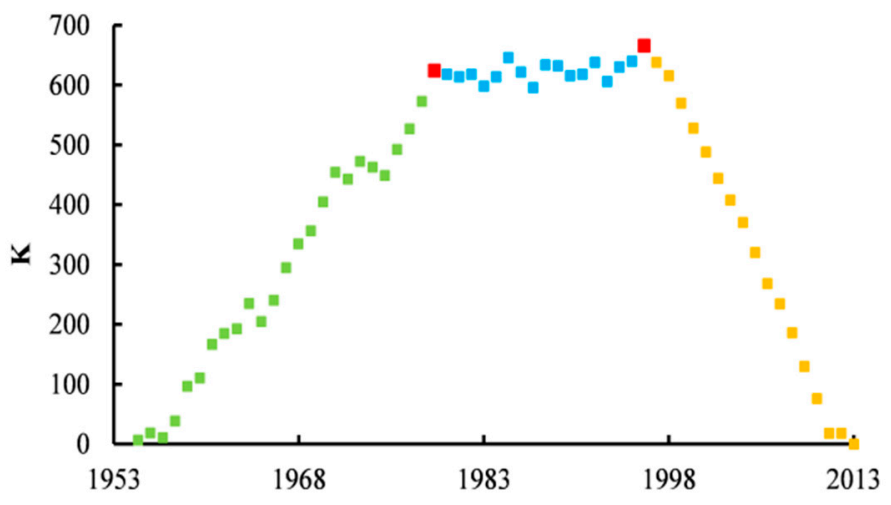

Figure 5. K value change calculated by Pettitt test.

\subsection{Separating the Impacts of Climate Change and Human Activities by MWBM}

\subsubsection{Model Calibration and Verification}

In this study, we took $1955-1978$ as the baseline period. The observed climatic and streamflow data at the Wenjiachuan station in 1955-1970 was used for calibration, and the data from 1971 to 1978 were used for verification. Figure 6 show that the recorded and simulated data fit well. The points of the correlation between recorded and simulated streamflow are concentrated around the 1:1 line (Figure 7). In addition, The NSE in calibration period and verification period were $77.95 \%$ and $75.69 \%$, respectively. Furthermore, the RE were $3.58 \%$ and $4.21 \%$. Overall, the calibration and verification accuracies of the model were acceptable. The next step is investigating the effect of climate change and human activities in the human-induced periods by the MWBM.

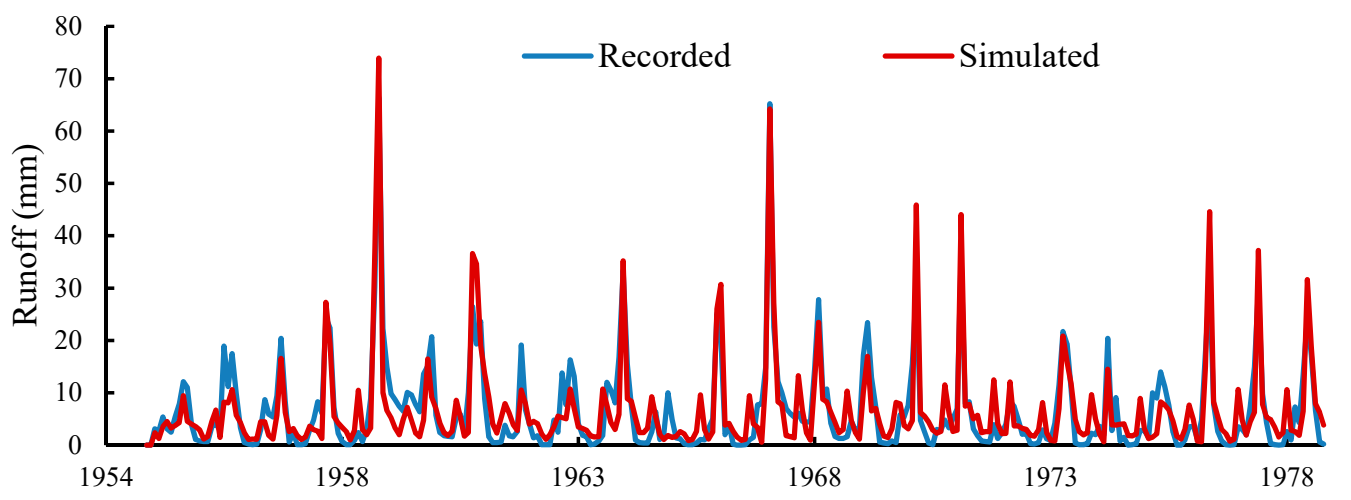

Figure 6. Monthly time series of recorded streamflow and simulated streamflow in 1955-1978 at Wenjiachuan station. 


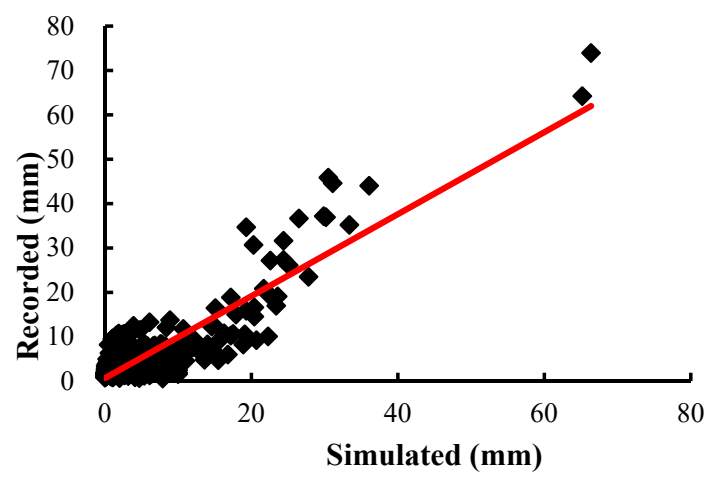

Figure 7. Correlation between simulated and recorded monthly streamflow in the baseline period.

\subsubsection{Separating the Impacts of Climate Change and Human Activities}

According to the abrupt change years, the streamflow series were divided into periods of the baseline period (1955-1978), human impacted (HIP) period (1979-1996), and human strong induced (HSIP) period (1997-2013), respectively. Given the recorded streamflow and reconstructed streamflow, the influence of climate change and human activities on streamflow in HIP and HSIP are summarized in Table 1.

Table 1. The contributions of climate change and human activities to annual streamflow reduction.

\begin{tabular}{|c|c|c|c|c|c|c|c|c|}
\hline \multirow{2}{*}{ Periods } & \multirow{2}{*}{$\begin{array}{l}\text { Recorded } \\
\text { Streamflow } \\
(\mathrm{mm})\end{array}$} & \multirow{2}{*}{$\begin{array}{l}\text { Reconstructed } \\
\text { Streamflow } \\
(\mathrm{mm})\end{array}$} & \multicolumn{2}{|c|}{ Total Change (\%) } & \multicolumn{2}{|c|}{$\begin{array}{c}\text { Impact by } \\
\text { Climate Change }\end{array}$} & \multicolumn{2}{|c|}{$\begin{array}{c}\text { Impact by } \\
\text { Human Activities }\end{array}$} \\
\hline & & & $\begin{array}{c}\Delta Q \\
(\mathrm{~mm})\end{array}$ & $\eta(\%)$ & $\begin{array}{c}\Delta Q_{\mathrm{c}} \\
(\mathrm{mm})\end{array}$ & $\eta_{c}(\%)$ & $\begin{array}{c}\Delta Q_{h} \\
(\mathrm{~mm})\end{array}$ & $\eta_{h}(\%)$ \\
\hline 1955-1978 & 81.02 & & & & & & & \\
\hline 1979-1996 & 63.12 & 68.32 & -17.90 & 22.09 & -12.7 & 70.95 & -5.20 & 29.05 \\
\hline 1997-2013 & 25.93 & 68.01 & -55.09 & 67.99 & -13.01 & 23.62 & -42.08 & 76.38 \\
\hline 1979-2013 & 45.06 & 68.17 & -35.96 & 44.38 & -12.85 & 35.73 & -23.11 & 64.27 \\
\hline
\end{tabular}

During the period of 1979-2013, the recorded annual streamflow was obviously less than that of the baseline period. The absolute and relative values of total impacts of climate change and human activities on annual streamflow were $-35.96 \mathrm{~mm}$ and $44.38 \%$. Both climate change and human activities resulted in streamflow decreases compared to the baseline period. During 1979-1996, the climate change was the main factor that decreased streamflow with a contribution of $70.95 \%$ relative to the baseline period, while the reduction percentage due to human activities were only $29.05 \%$. However, the contribution of climate variations to streamflow reduction dropped to $23.62 \%$, corresponding that of human activities which ascended to $76.38 \%$ in 1997-2013. Human activity has become the major factor in reducing streamflow. Specific impacts of climate change on annual streamflow were $-12.7 \mathrm{~mm}$ for HIP and $-13.01 \mathrm{~mm}$ for HSIP, while the influence of human activities were from $-5.20 \mathrm{~mm}$ in HIP to $-42.08 \mathrm{~mm}$ in HSIP. On average, human activities and climate change were responsible for $64.27 \%$ and $35.73 \%$ of streamflow reduction, respectively.

\subsection{Separating the Coal Mining and SWC Impacts on Streamflow Decreasing}

The SWC in Kuye River Basin includes the construction of terraces, planting trees and afforestation, and building sediment-trapping dams. Water and soil loss is severe in the Kuye River Basin. Before 1979, the area of SWC was generally small, and less than 7\% of the basin area. After 1979, a large number of SWC were carried out. Because there are not the information about the areas of the different SWC in every year. The analysis uses the areas in the survey years. The water reduction of SWC are calculated in HIP and HQIP by the water reduction coefficient and the areas of SWC in the representative years 
(Table 2). The streamflow reduction caused by the SWC from $-3.05 \mathrm{~mm}$ in HIP to $-12.20 \mathrm{~mm}$ in HQIP. During 1979-2013, the average annual streamflow reduction was $-7.57 \mathrm{~mm}$.

Table 2. Cumulative area of SWC since the 1950s.

\begin{tabular}{|c|c|c|c|c|c|c|c|c|}
\hline \multirow[b]{2}{*}{ Year } & \multicolumn{2}{|c|}{ Terrace } & \multicolumn{2}{|c|}{ Afforestation } & \multicolumn{2}{|c|}{ Grassland } & \multicolumn{2}{|c|}{ Sediment-Trapping Dams } \\
\hline & $\underset{\left(\mathbf{k m}^{2}\right)}{\mathrm{A}}$ & $\begin{array}{c}\mathcal{\varepsilon} \\
\left(\mathrm{m}^{3} / \mathrm{km}^{2}\right)\end{array}$ & $\underset{\left(\mathbf{k m}^{2}\right)}{\mathrm{A}}$ & $\begin{array}{c}\mathcal{\varepsilon} \\
\left(\mathrm{m}^{3} / \mathrm{km}^{2}\right)\end{array}$ & $\underset{\left(\mathrm{km}^{2}\right)}{\mathrm{A}}$ & $\begin{array}{c}\mathcal{E} \\
\left(\mathrm{m}^{3} / \mathrm{km}^{2}\right)\end{array}$ & dam & $\underset{\left.\text { (per dam } / \mathrm{m}^{3}\right)}{\mathcal{E}}$ \\
\hline 1959 & 5 & & 27 & & 22 & & 0 & \\
\hline 1969 & 33 & & 97 & & 52 & & 2 & \\
\hline 1979 & 66 & & 415 & & 110 & & 8 & \\
\hline 1989 & 67 & 44,600 & 1004 & 20,900 & 353 & 16,600 & 12 & 12,000 \\
\hline 1996 & 99 & & 1184 & & 380 & & 19 & \\
\hline 2009 & 101 & & 2652 & & 938 & & 1548 & \\
\hline 2013 & 105 & & 3555 & & 638 & & 2271 & \\
\hline
\end{tabular}

Based on the influence of human activities and the SWC to annual streamflow reduction, respectively, we could calculate the contribution of coal mining to runoff reduction (Table 3). The average annual impact of the coal mining on streamflow were from $-2.15 \mathrm{~mm}$ in HIP to $-29.88 \mathrm{~mm}$ in HQIP. The percentage of the effect was increasing from $41.35 \%$ to $71.02 \%$. However, the percentage of the effect for the SWC was decreasing from $58.65 \%$ to $28.99 \%$. Seen from the impact quantity, the contribution of coal mining and SWC on streamflow decreasing showed an increasing trend. At the same time, the growth rate of the impact of coal mining was greater than that of the SWC. During 1979-2013, the influence of the SWC and the coal mining on streamflow was $-7.57 \mathrm{~mm}, 32.76 \%$ and $-15.54 \mathrm{~mm}$, $67.24 \%$, respectively. Thus, the coal mining demonstrated the dominant influence on streamflow decline gradually.

Table 3. The contributions of the SWC and coal mining to annual streamflow reduction.

\begin{tabular}{cccccc}
\hline \multirow{2}{*}{ Period } & \multirow{2}{*}{$\begin{array}{c}\text { Impact by Human } \\
\text { Activities (mm) }\end{array}$} & \multicolumn{2}{c}{ Impact by SWC } & \multicolumn{2}{c}{ Impact by Coal Mining } \\
\cline { 3 - 6 } & & $\Delta \mathbf{Q}_{\mathbf{s b}} \mathbf{( m m )}$ & $\eta_{\mathbf{s b}} \mathbf{( \% )}$ & $\Delta \mathbf{Q}_{\mathbf{c m}} \mathbf{( m m )}$ & $\eta_{\mathbf{c m}} \mathbf{( \% )}$ \\
\hline $1979-1996$ & -5.20 & -3.05 & 58.65 & -2.15 & 41.35 \\
$1997-2013$ & -42.08 & -12.20 & 28.99 & -29.88 & 71.02 \\
$1979-2013$ & -23.11 & -7.57 & 32.76 & -15.54 & 67.24 \\
\hline
\end{tabular}

\subsection{Quantification Climate Change, Coal Mining and SWC Impacts on Streamflow Decreasing}

Based on separating the impacts of climate change and human activities, and the contribution of coal mining and SWC among human activities, we could quantify the influence of climate change, coal mining and SWC on annual streamflow decline (Table 4). During 1979-1996, the annual runoff reduction was $-17.90 \mathrm{~mm}$ induced by climate change, coal mining and SWC, among which the impacts of climate change was $-12.70 \mathrm{~mm}, 70.95 \%$; that of coal mining was $-2.15 \mathrm{~mm}, 12.01 \%$; and that of SWC was $-3.05 \mathrm{~mm}, 17.04 \%$, climate change was the main influencing factor. However, in 1997-2013, the impact of coal mining on annual streamflow was $-29.88 \mathrm{~mm}$, and that of climate change and SWC were $-13.01 \mathrm{~mm}$ and $-12.20 \mathrm{~mm}$. The relative values of impacts were $54.24 \%$ for coal $\mathrm{mining}, 23.62 \%$ for climate change, and $22.14 \%$ for the SWC, respectively. 
Table 4. The quantification of impacts of climate change, coal mining and SWC on streamflow decreasing.

\begin{tabular}{|c|c|c|c|c|c|c|c|}
\hline \multirow[b]{2}{*}{ Periods } & \multirow{2}{*}{$\begin{array}{l}\text { Total Change } \\
(\mathrm{mm})\end{array}$} & \multicolumn{2}{|c|}{ Impact by Climate Change } & \multicolumn{2}{|c|}{ Impact by Coal Mining } & \multicolumn{2}{|c|}{ Impact by SWC } \\
\hline & & $\Delta Q_{c}(\mathrm{~mm})$ & $\eta_{c}(\%)$ & $\Delta Q_{\mathrm{cm}}(\mathrm{mm})$ & $\eta_{\mathrm{cm}}(\%)$ & $\begin{array}{l}\Delta Q_{\mathrm{sb}} \\
(\mathrm{mm})\end{array}$ & $\begin{array}{l}\eta_{\mathrm{sb}} \\
(\%)\end{array}$ \\
\hline 1979-1996 & -17.90 & -12.70 & 70.95 & -2.15 & 12.01 & -3.05 & 17.04 \\
\hline 1997-2013 & -55.09 & -13.01 & 23.62 & -29.88 & 54.24 & -12.20 & 22.14 \\
\hline 1979-2013 & -35.96 & -12.85 & 35.73 & -15.54 & 43.22 & -7.57 & 21.05 \\
\hline
\end{tabular}

\section{Discussion}

\subsection{Impact of Climate Change and Human Activities on Streamflow}

In recent decades, the streamflow of many rivers around the world exhibited a decreasing trend because of climate change and human activity [42]. Over the past 40 years in the Central Rift Valley of Ethiopia, almost all rainfall indices have an increasing trend in the valley floor and a decreasing trend in the escarpment and highlands [43]. For responding to the effects of climate change, and simultaneously satisfy environmental, societal, and economic, the implementation of environment friendly techniques policies in Romania have been studied [44]. The research found that a $10 \%$ decrease in precipitation may cause a decrease in streamflow of between $19 \%$ in the tropical zone and $30 \%$ in the arid zone in Africa [45]. Climate change may contribute $26 \%-31 \%$ of streamflow decline relative to the base period in Beichuan river basin of China [46]. In northwest China, the streamflow reduction caused by climate change accounting for 14.3\% [47]. For the tributaries in the middle reaches of the Yellow River basin, climate change accounted for more of the streamflow reduction in the Beiluo River and Yan River, while human activities has a greater effect on the streamflow reduction in other tributaries [48]. In this study, climate change along with human activity led to a decrease in streamflow in HIP to HSIP. However, the contribution of climate to streamflow reduction was in a relatively stable state, and the absolute amount of influence was $-12.7 \mathrm{~mm}$ in HIP and $-13.01 \mathrm{~mm}$ in HSIP. By contrast, the contributions of human activities to streamflow reduction between HIP and HSIP were significantly different and have an enhanced trend from $-5.20 \mathrm{~mm}$ in HIP to $-42.08 \mathrm{~mm}$ in HSIP. The two abrupt points of streamflow change were in 1979 and 1996, which were in consonance with the extensive SWC in the late 1970s (Table 2) and the massive coal mining in the late 1990s (Figure 9). During the HIP period, the contributions of climate change reached $70.95 \%$, and was the main factor affecting streamflow reduction due to the low intensity of human activity. But, the total amount of streamflow decreasing significantly increased from $-17.90 \mathrm{~mm}$ to $-55.09 \mathrm{~mm}$ to the HSIP, and $76.38 \%$ of the contributions was due to human activities, indicating that intensity of human activities has increased significantly since the end of 1990s.

\subsection{Impacts of Coal Mining on Streamflow}

The contribution of coal mining impacts on streamflow decline increased $-27.73 \mathrm{~mm}$ from HIP to HSIP, and became the dominant factor affecting streamflow in HSIP. It is related to the dramatic increase in coal mining since the end of the 20th century (Figure 8). Raw coal production increased from $1102.58 \times 10^{4} \mathrm{t}$ in 1996 to $17,262.21 \times 10^{4} \mathrm{t}$ in 2011 which was 15 times that of 1996. A large number of coal mining produced significant impact on streamflow. The surface of mining areas are the aeolian sand of the Sarawusu Formation. The Quaternary Sarawusu group loose pore phreatic aquifer is significant for water supply, and the coal seam is under the Sarawusu group aquifer. After coal seam mining, the water conducting fissure extended to the surface (Figure 9) [49], which not only increased rainfall infiltration, but also lowered the phreatic level. The rapid loss of the phreatic and surface water inevitably led to streamflow reduction. 


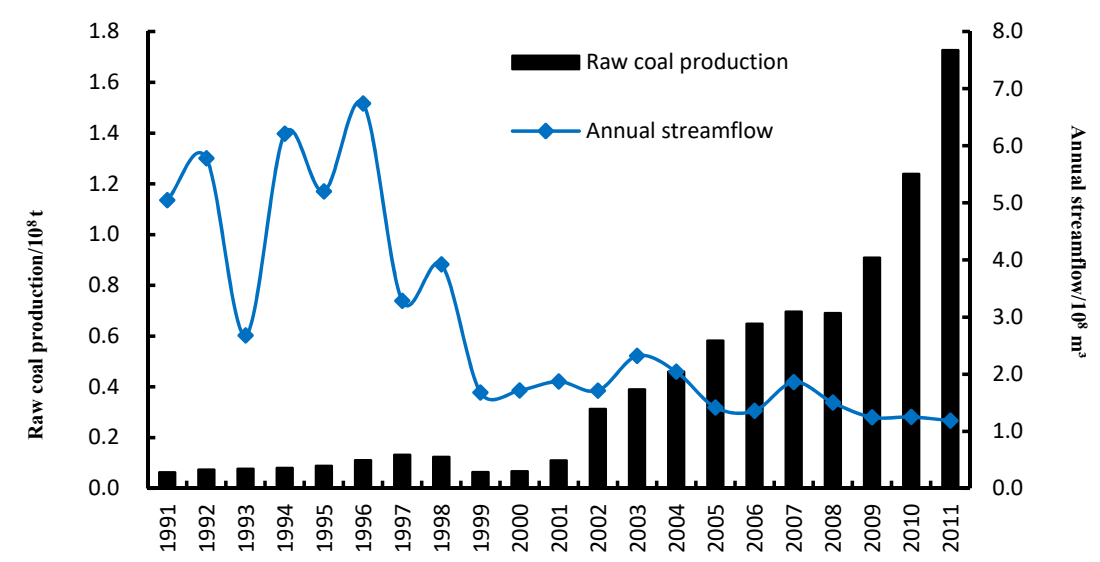

Figure 8. Relation of raw coal production and annual streamflow in Kuye River Basin.

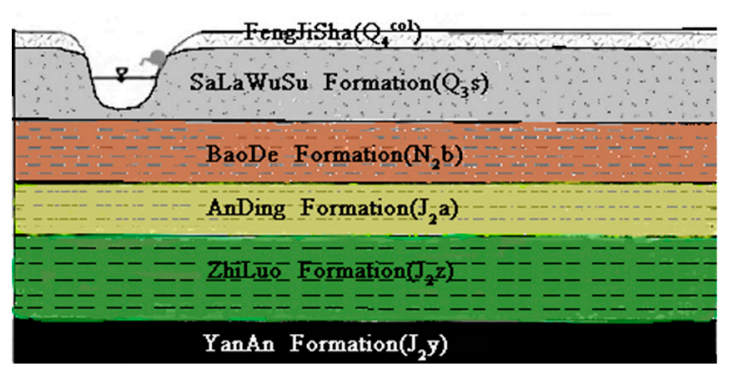

(a)

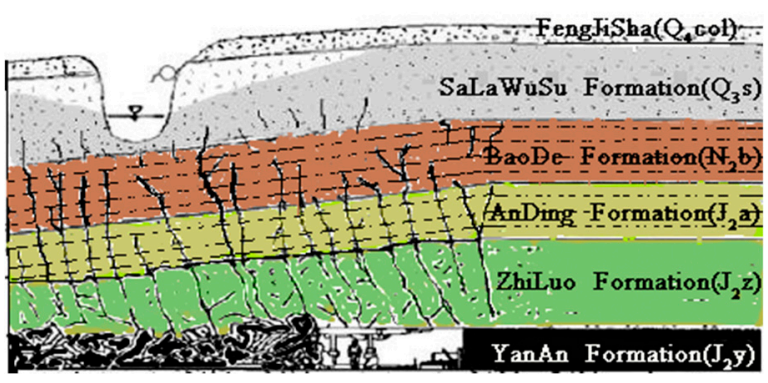

(b)

Figure 9. The coal mine aquifer in Kuye River Basin. (a) Before coal mining; (b) After coal mining.

\subsection{Impacts of SWC on Streamflow}

SWC techniques are widely used to alter soil and water processes and improve ecosystem environment. A study of sample plots from 22 countries indicated that afforestation, soil amendment and terraces may reduce annual streamflow by $55 \%, 48 \%$ and $44 \%$ respectively [50]. Both catch crops and weeds may enhance infiltration rates, delay and decrease the runoff discharge under single ring ponding conditions [51]. A cover of $50 \%$ of straw is able to delay the time to runoff initiation from 57 to $129 \mathrm{~s}$, and mulching reduces the runoff coefficient from 65.6 to $50.5 \%$ in clementine plantations [52]. Surface runoff may be reduced by about $19 \%$ by the SWC in Ethiopian [53]. On the most severely eroded Loess Plateau in the world, large scale SWC were implemented, which induced streamflow decline [54]. The construction of terraces, planting trees and afforestation, and building sediment-trapping dams were the main measures of SWC in the watersheds which located on Loess Plateau. After building terracing, the topography of the basin has been changed, the rainfall infiltration has been greatly improved, and streamflow has been reduced. After planting trees and afforestation on bare hill slopes, a considerable proportion of rainfall can be intercepted by the canopy and evaporate into the atmosphere. Thus, the effective rainfall for runoff generation is reduced. The sediment-trapping dams are built in the ditch and channel of the Loess Plateau, and may intercept floods, and is an important measure to prevent water and soil loss. Although the percentage of the contribution of SWC impacts on streamflow reduction has decreased. In fact, its absolute amount of the contribution of SWC impacts on streamflow decline increased $-9.15 \mathrm{~mm}$, indicating the contributions of coal mining and SWC streamflow reduction were on an increasing trend, while the increase rate of coal mining was greater.

\subsection{Uncertainties of Quantitative Assessment}

The uncertainty of quantitative assessment came mainly from the following aspects. (1) Model parameters and input data may lead to uncertainty in the simulation process. For instance, in this study only mean monthly temperature and monthly total precipitation are as the climatic input data 
which should actually include sunshine, wind speed, evaporation and other factors. (2) We analyzed the contribution of climate change and human activities to streamflow variation with the assumption that the streamflow in the baseline period was not affected by human activities. However, in fact, the streamflow was also affected by human activities although with less intensity. (3) In this study, only coal mining and SWC were considered as elements of human activities affecting streamflow, and not considered water consumption for domestic, irrigation, and industry which also has the impact on streamflow. for example, Shenmu County, which accounts for more than $50 \%$ of the basin area, increased industrial water supply by nearly 10 times from 1980 to 2011; and the construction of the massive water landscape and urban grassland has increased evaporation loss and irrigation water consumption. So the quantitative assessment values of the contribution of coal mining and SWC were higher than the actual values. (4) It should also be note that the influence of climate change, coal mining and SWC on streamflow are not independent in theory and cannot be separated exactly. These factors interact with each other.

\subsection{Prospects for Future Research}

The researched watershed is located in the water and soil erosion zone of the Loess Plateau. The surface gully is vertical and horizontal, the terrain is broken, the loess is loose, the vegetation is scarce. At the same time, a large number of coal mines are distributed along the river, and the coal seams are shallow. Similar rivers in the middle reaches of the Yellow River include Wuding River, Tuwei River, etc. The commonality of these basins are: (1) the fragile ecological environment; (2) the main source of sediment in the Yellow River; (3) coal mining and SWC are the main human activities. The research conclusions are applicable to such watershed mentioned above. However, for the other coal mining concentrated watershed, the impact of coal mining on streamflow should been further studied. In addition, in this study, the water reduction of SWC are calculated by the water reduction coefficient and the areas of SWC in the representative years, and it made the accuracy of the results was affected to a certain extent. Future research should utilize hydrological models to effectively separate the effects of different types of human activity to streamflow.

\subsection{Adaptive Strategies and Options}

There are many watersheds in which coal mining and SWC are the main human activities on the Loess Plateau, for example, the Tuwei River Basin and the Wudin River Basin. Some previous studies indicate that the abrupt points of streamflow change were also in 1979 and 1996 for the Tuwei River and the Wudin River $[55,56]$. The contribution of climate change and human activities to streamflow reduction were $57.95 \%$ and $42.05 \%$ from 1997 to 1996, respectively. Nevertheless, the contribution of climate change dropped to $24.19 \%$, and that of human activities ascended to $75.81 \%$ after 1996 in the Tuwei River basin. For the Wuding River, the contribution of climate change was $79.8 \%$ from the 1970s to the end of the 1990s, and human activity became the main factor affecting streamflow reduction to the 21st century [57]. The common features of these rivers are that they are located on the Loess Plateau and the ecological environment there is fragile. To protect water resources, local governments should adopt strategies such as strengthening water resources protection and popularizing water-preserving technology in coal mining, developing water saving irrigation technology, and reusing and recycling water resources in industry.

\section{Conclusions}

In this paper, we analyzed streamflow change trends, abrupt change years from 1955 to 2013, separated the contributions of climate change, coal mining and SWC impacts on streamflow decreasing. The main findings are as follows:

(1) The annual runoff presented a decreasing trend, and passed the 0.05 significance test during 1955-2013.The two significant change years was in 1979 and 1996. 
(2) In the first impact period (1979-1996), climate change was the main factor for annual streamflow decreasing. Meanwhile, in the second impact period (1997-2013), coal mining was the dominant influence on streamflow decline.

(3) Compare two impact periods, the absolute value of climate change, coal mining and SWC impacts on streamflow reduction were all ascending, which indicated that the impacts of above three factors on streamflow decreasing were increasing. Meanwhile, the growth rate of coal mining impact on streamflow decline was greater than that of climate change and SWC.

(4) Quantifying the impacts of climate change, coal mining and SWC on streamflow decline by the MWBM and field investigation was reasonable and feasible.

Author Contributions: Q.G., Y.H. and Y.Y. conceived the study, analyzed the data and wrote the paper. G.F. and J.L. provided critical feedback on the manuscript.

Funding: This research work was supported by Key Research Project of colleges and universities of Henan Province in China (No.18A170006), Soft Science Research Project of Henan Province in China (No.182400410045), Soft Science Research of Key Research Project of colleges and universities of Henan Province in China (No.19A630013), Henan Provincial Natural Science Foundation Project of China (No.182300410155), The Innovation Scientists and Technicians Troop Construction Projects of Henan Province (No. CXTD2016053).

Conflicts of Interest: The authors declare no conflict of interest.

\section{References}

1. Jiang, C.; Xiong, L.H.; Wang, D.B.; Liu, P.; Guo, S.L.; Xu, C.Y. Separating the impacts of climate change and human activities on runoff using the Budyko-type equations with time-varying parameters. J. Hydrol. 2015, 522, 326-338. [CrossRef]

2. Bao, Z.X.; Zhang, J.Y.; Wang, G.Q.; Fu, G.B.; He, R.M.; Yan, X.L.; Jin, J.L.; Liu, Y.L.; Zhang, A.J. Attribution for decreasing streamflow of the Haihe River basin, northern China: Climate variability or human activities? J. Hydrol. 2012, 460-461, 117-129. [CrossRef]

3. Fu, G.B.; Chen, S.L.; Liu, C.M.; Shepard, D. Hydro-climatic trends of the Yellow River Basin for the last 50 years. Clim. Chang. 2004, 65, 149-178. [CrossRef]

4. Milliman, J.D.; Farnsworth, K.L.; Jones, P.D.; Xu, K.H.; Smith, L.C. Climatic and anthropogenic factors affecting river discharge to the global ocean, 1951-2000. Glob. Planet. Chang. 2008, 62, 187-194. [CrossRef]

5. Arrigoni, A.S.; Greenwood, M.C.; Moore, J.N. Relative impact of anthropogenic modifications versus climate change on the natural flow regimes of rivers in the northern Rocky Mountains, United States. Water Resour. Res. 2010, 46. [CrossRef]

6. Tu, A.G.; Xie, S.H.; Yu, Z.B.; Li, Y.; Nie, X.F. Long-term effect of soil and water conservation measures on runoff, sediment and their relationship in an orchard on sloping red soil of southern China. PLoS ONE 2018, 13, e0203669. [CrossRef] [PubMed]

7. Rossi, A.; Massei, N.; Laignel, B.; Sebag, D.; Copard, Y. The response of the Mississippi River to climate fluctuations and reservoir construction as indicated by wavelet analysis of streamflow and suspended sediment load, 1950-1975. J. Hydrol. 2009, 377, 237-244. [CrossRef]

8. Zhao, G.; Mu, X.; Wen, Z.; Wang, F.; Gao, P. Soil erosion, conservation, and eco-environment changes in the Loess Plateau of China. Land Degrad. Dev. 2013, 24, 499-510. [CrossRef]

9. Shi, H.; Shao, M.A. Soil and water loss from the Loess Plateau in China. J. Arid Environ. 2000, 45, 9-20. [CrossRef]

10. Chen, L.D.; Wei, W.; Fu, B.J.; Lv, Y.H. Soil and water conservation on the Loess Plateau in China: Review and perspective. Prog. Phys. Geogr. 2007, 31, 389-403. [CrossRef]

11. Xu, J.H.; Niu, Y.G. Influence of Water Conservancy Project on Runoff and Sediment in Coarse Sand Area of the Middle Reaches of the Yellow River; The Yellow River Water Conservancy: Zhengzhou, China, 2000; p. 6.

12. Liu, H.B.; Wang, G.Q.; Jian, H.R.; Wang, M.M. Research on the hydrological effects of soil and water conservation in the Qingjianhe River Basin of Loess Plateau. J. Water Resour. Water Eng. 2009, 20, 7-11.

13. Kang, L.L.; Wei, Y.C.; Zhang, S.L.; Liu, X.Q. Macroscopic analysis of runoff utilization for soil and water conservation in Loess Plateau. J. Water Resour. Water Eng. 2010, 21, 108-112. 
14. Zhu, C.G. Soil and water conservation and ecological environment construction on the Loess Plateau. Sci. Technol. Innov. 2018, 17, 90-91.

15. Guo, Q.L.; Su, N.; Yang, Y.S.; Li, J.L.; Wang, X.Y. Using hydrological simulation to identify contribution of coal mining to runoff change in the Kuye river basin, China. Water Resour. 2017, 44, 586-594. [CrossRef]

16. Chiew, F.H.S.; Fu, G.B.; Post, D.A.; Zhang, Y.Q.; Wang, B.; Viney, N.R. Impact of coal resource development on streamflow characteristics: Influence of climate variability and climate change. Water 2018, 10, 1161. [CrossRef]

17. Pan, G. Impact Studies on the Mechanism and Quantitative Model of Coal Mining on River Runoff in Gujiao City of Shanxi Province. Master's Thesis, Zhengzhou University, Zhengzhou, China, 2015; p. 2.

18. Li, Q.Y.; Cai, Q.; Fang, H.Y. Contribution characteristics of wind erosion to the sediment yield in the Kuyehe River Watershed at time scales. J. Nat. Resour. 2011, 26, 674-682.

19. Luo, T.; Wang, W.L.; Wang, Z.; Jin, J. Experiment of water runoff and sediment yield on the disturbed lands in Shenfu-Dongsheng coalfield development and construction. J. Northwest For. Univ. 2011, 26, 59-63.

20. Su, H.; Kang, W.D.; Cao, Z.Z.; Zhu, L. Analysis on precipitation and runoff changing trend from 1954 to 2009 in Kuye River Basin. Ground Water 2013, 35, 14-17.

21. Guo, Q.L.; Xiong, X.Z.; Hao, B.; Bai, L. Variation trends of seasonal runoff distribution in Kuyehe basin over the past 50 years. J. Arid Land Resour. Environ. 2014, 28, 35-40.

22. Zhao, X.K.; Wang, S.J. Analysis on the flood characteristics and its change trend in the Kuye River Basin. J. Arid Land Resour. Environ. 2012, 26, 92-96.

23. Liu, E.J.; Zhang, X.P.; Zhang, J.J.; Lei, Y.N.; Xie, M.L. Variation of annual streamflow and the effect of human activity in the Kuye River during 1956 to 2005. J. Nat. Resour. 2013, 28, 1159-1168.

24. Bai, L.; Li, H.E.; He, H.M. Analysis on detection and attribution of runoff change in Kuye River Basin. J. Hydroelectr. Eng. 2015, 34, 15-22.

25. Li, Z.; Liu, W.Z.; Zhang, X.C.; Zheng, F.L. Impacts of land use change and climate variability on hydrology in an agricultural catchment on the Loess Plateau of China. J. Hydrol. 2009, 377, 35-42. [CrossRef]

26. Wang, M.L.; Guo, S.L. A primary analysis of runoff regime in the Yellow River Basin based on monthly water balance model. Water Resour. Water Eng. 1999, 10, 1-6.

27. Xing, X.P.; Zhang, W.Z.; Tang, F.F.; Liu, S.S.; Niu, H.J. Hydrological simulation of water balance model in the Kuyehe River catchment. J. Water Resour. Water Eng. 2012, 23, 73-78.

28. Guo, Q.L.; Han, Z.Y.; Yang, L.J.; Xiong, X.Z. Hydrological simulation of impacts of coal mining on surface runoff in Kuye River. Adv. Sci. Technol. Water Resour. 2015, 35, 19-22.

29. Cheng, L.; Xu, Z.X.; Luo, R.; Mi, Y.J. SWAT application in arid and semi-arid region: A case study in the Kuye River Basin. Geogr. Res. 2009, 28, 65-73.

30. Li, S.; Chen, Y.; Li, Z.J.; Yang, F.L. Study of coal mining disturbance to simulated monthly runoff values of Kuye River. Yellow River 2016, 38, 13-17.

31. Liang, K.; Liu, C.M.; Liu, X.M.; Song, X.F. Impacts of climate variability and human activity on streamflow decrease in a sediment concentrated region in the Middle Yellow River. Stoch. Env. Res. Risk Assess 2013, 27, 1741-1749. [CrossRef]

32. Sui, J.Y.; He, Y.; Liu, C. Changes in sediment transport in the Kuyeriver in the loess plateau in China. Int. J. Sediment Res. 2009, 24, 201-213. [CrossRef]

33. Wang, G.Q.; Zhang, J.J.; Li, Y.; Liu, C.S.; Bao, Z.X.; Jin, J.L. Analysis of runoff evolution and factor of driving force in Kuye river catchment. J. Water Resour. Water Eng. 2014, 25, 7-11.

34. Wu, X.J.; Li, H.E.; Dong, Y.; Liu, T.L. Quantitative identification of coal mining and other human activities on river runoff in northern Shaanxi region. Acta Sci. Circumst. 2014, 34, 772-780.

35. Wang, L.; Wei, S.P.; Wang, Q.J. Effect of coal exploitation on groundwater and vegetation in the Yushenfu coal mine. J. China Coal Soc. 2008, 33, 1408-1413.

36. Hamed, K.H.; Rao, A.R. A modified Mann-Kendall trend test for autocorrelated data. J. Hydrol. 1998, 204, 182-196. [CrossRef]

37. Pettitt, A.N. A nonparametric approach to the change-point problem. Appl. Stat. 1979, 28, 126-135. [CrossRef]

38. Ran, D.C.; Zuo, Z.G.; Wu, Y.H.; Li, X.M.; Li, Z.H. Response of Water and Sediment to Human Activities Changes in the Middle Reaches of the Yellow River; Science Press: Beijing, China, 2012; p. 125.

39. Thornthwaite, C.W. An approach toward a rational classification of climate. Geogr. Rev. 1948, 38, 55-94. [CrossRef] 
40. McCabe, G.J.; Markstrom, S.L. A Monthly Water-Balance Model Driven by a Graphical User Interface; Open-File Report 2007-1088; U.S. Geological Survey: Reston, VA, USA, 2007; p. 6.

41. Jiang, X.H.; Gu, X.W.; He, H.M. The influence of coalmining on water resources in the Kuye River Basin. J. Nat. Resour. 2010, 25, 300-307.

42. Wu, L.H.; Wang, S.J.; Bai, X.Y.; Luo, W.J.; Tian, Y.C.; Zeng, C.; Luo, G.J.; He, S.Y. Quantitative assessment of the impacts of climate change and human activities on runoff change in a typical karst watershed, SW China. Sci. Total Environ. 2017, 601-602, 1449-1465. [CrossRef] [PubMed]

43. Alemayehu, M.; Woldeamlak, B.; Saskia, K.; Leo, S. Searching for evidence of changes in extreme rainfall indices in the Central Rift Valley of Ethiopia. Theor. Appl. Climatol. 2016, 1-15. [CrossRef]

44. Rares, H.C.Z.; Saskia, K.; Zahra, K. The impact of political, socio-economic and cultural factors on implementing environment friendly techniques for sustainable land management and climate change mitigation in Romania. Sci. Total Environ. 2019, 654, 418-429.

45. Hasan, E.; Tarhule, A.; Kirstetter, P.; Clark, R.; Yang, H. Runoff sensitivity to climate change in the Nile River Basin. J. Hydrol. 2018, 561, 312-321. [CrossRef]

46. Wang, X.B.; He, K.N.; Dong, Z. Effects of climate change and human activities on runoff in the Beichuan River Basin in the northeastern Tibetan Plateau, China. CATENA 2019, 176, 81-93. [CrossRef]

47. Li, Y.Z.; Liu, C.M.; Yu, W.J.; Tian, D.; Bai, P. Response of streamflow to environmental changes: A Budyko-type analysis based on 144 river basins over China. Sci. Total Environ. 2019, 664, 824-833. [CrossRef]

48. Zhao, G.J.; Tian, P.; Mu, X.M.; Jiao, J.Y.; Wang, F.; Gao, P. Quantifying the impact of climate variability and human activities on streamflow in the middle reaches of the Yellow River basin, China. J. Hydrol. 2014, 519, 387-398. [CrossRef]

49. Lyu, X.; Wang, S.M.; Yang, Z.Y.; Bian, H.Y.; Liu, Y. Influence of coal mining on water resources: A case study in Kuye river basin. Coal Geol. Explor. 2014, 42, 54-57.

50. Xiong, M.Q.; Sun, R.H.; Chen, L.D. Effects of soil conservation techniques on water erosion control: A global analysis. Sci. Total Environ. 2018, 645, 753-760. [CrossRef]

51. Artemi, C.; Jesus, R.C.; Antonio, G.M.; Saskia, K. Hydrological and erosional impact and farmer's perception on catch crops and weeds in citrus organic farming in Canyoles river watershed, Eastern Spain. Agric. Ecosyst. Environ. 2018, 1-11. [CrossRef]

52. Keesstra, S.D.; Rodrigo, C.J.; Novara, A.; Gimenez, M.A.; Pulido, M.; Di Prima, S.; Cerda, A. Straw mulch as a sustainable solution to decrease runoff and erosion in glyphosate-treated clementine plantations in Eastern Spain. An assessment using rainfall simulation experiments. CATENA 2018. [CrossRef]

53. Melaku, N.D.; Renschler, G.S.; Flagler, J.; Bayu, W. Integrated impact assessment of soil and water conservation structures on runoff and sediment yield through measurements and modeling in the Northern Ethiopian highlands. CATENA 2018, 169, 140-150. [CrossRef]

54. Jiang, C.; Zhang, H.Y.; Wang, X.C.; Feng, Y.Q.; Labzovskii, L. Challenging the land degradation in China's Loess Plateau: Benefits, limitations, sustainability, and adaptive strategies of soil and water conservation. Ecol. Eng. 2019, 127, 135-150. [CrossRef]

55. Ren, Z.P.; Ma, Y.Y.; Wang, Y.S.; Xie, M.Y.; Li, P. Runoff changes and attribution analysis in tributaries of different geomorphic regions in Wuding River under ecological construction. Acta Ecol. Sin. 2019, 39, 1-10.

56. Li, Z.L. Effects of Environmental Changes on Runoff Situation in the Tuwei River Basin. Master's Thesis, Xi'an University of Technology, Xi'an, China, 2018.

57. Jiao, Y.; Lei, H.M.; Yang, D.W.; Yang, H.B. Attribution of discharge changes over Wuding River watershed using a distributed eco-hydrological model. J. Hydroelectr. Eng. 2017, 36, 34-44.

(C) 2019 by the authors. Licensee MDPI, Basel, Switzerland. This article is an open access article distributed under the terms and conditions of the Creative Commons Attribution (CC BY) license (http://creativecommons.org/licenses/by/4.0/). 